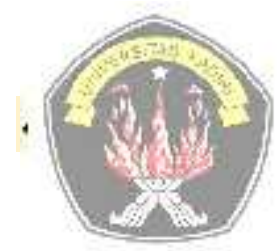

Tersedia online di

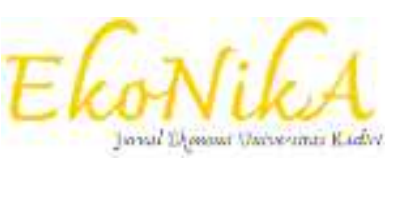

\title{
Pengaruh Bank Sampah Terhadap Pemberdayaan Ibu Rumah Tangga (Studi Kasus di Bank Sampah Kurabu Kota Padang Panjang)
}

\author{
Anno Suliza $^{1}$, Fery Andrianus $^{2}$, Chairul $^{3}$ \\ 1,2,3 Universitas Andalas
}

email: ${ }^{1}$ announdoamin01@gmail.com, ${ }^{2}$ feryandrianus2007@gmail.com,

\section{3hairul57@yahoo.com}

\section{Artikel History:}

Artikel masuk : 04-02-2020

Artikel revisi : 07-04-2020

Artikel diterima : 09-06-2020

Keywords:

Bank Sampah, Pemberdayaan, Ibu Rumah Tangga, Daur Ulang

\begin{abstract}
ABSTRAK
Bank Sampah merupakan program manajemen pengelolaan persampahan berbasis daur ulang yang digerakkan oleh peran dan partisipasi aktif anggota atau nasabahnya. Kelompok masyarakat berstatus Ibu Rumah Tangga (IRT) dinilai memiliki potensi sumber daya yang lebih untuk berkegiatan di Bank Sampah, sedangkan pemberdayaan nasabah menjadi indikator utama keberhasilan program tersebut. Kota Padang Panjang masih mempunyai rasio beban buangan akhir sampah yang cukup tinggi meskipun telah memiliki Bank Sampah. Tujuan penelitian untuk menganalisis beberapa variabel sehingga dapat mempengaruhi pemberdayaan Ibu Rumah Tangga. Jumlah responden sebanyak 74 orang diambil dengan purposive sampling dari Bank Sampah Kurabu di Kota Padang Panjang. Hasil analisis dengan metode SEM-PLS menunjukkan terdapat pengaruh signifikan dari edukasi tentang pengetahuan pemanfaatan sumber daya dan penumbuhan sikap peduli lingkungan terhadap pemberdayaan nasabah yang berstatus Ibu Rumah Tangga.
\end{abstract}

\section{ABSTRACT}

Waste Bank is a waste management based recycling management program that is driven by the active role and participation of members or customers. The community group with the status of Housewives are considered to have more potential resources for activities in the Waste Bank, while customer empowerment is the main indicator of the success of the program. The city of Padang Panjang still has a high final waste disposal ratio despite having a Waste Bank. The research objective is to analyze several variables so that they can influence the empowerment of Housewives. The number of respondents was 74 people taken by purposive sampling from the Kurabu Waste Bank in the city of Padang Panjang. The results of the analysis by the SEM-PLS method showed that there was a significant influence on education about the knowledge of resource utilization and the growth of an attitude of caring for the environment towards empowering customers who were housewives. 


\section{PENDAHULUAN}

Ketimpangan terhadap perempuan masih terjadi dalam berbagai sektor. Data WEF (World Economic Forum) menunjukkan bahwa Indonesia menempati rangking ke-85 dari 149 negara dalam hal kesetaraan gender yang meliputi indikator partisipasi ekonomi, pencapaian pendidikan, tingkat kesehatan dan pemberdayaan politik dengan skor 0,691 dari nilai maksimal 1 (World-Bank, 2018). Menurut Kementerian Pemberdayaan Perempuan dan Perlindungan Anak (KPPPA), perempuan selalu diberi upah lebih rendah dari laki-laki. Rata-rata upah perempuan adalah sebesar Rp 1,6 juta, atau 13\% lebih rendah dari upah laki-laki yang sebesar Rp 1,9 juta pada tahun 2015 (Ir. Anton Manurung et al., 2015). Pemberdayaan perempuan dan kesetaraan gender juga telah diamanatkan sebagai salah satu target global nomor 5 dalam SDG's yang berbunyi: "Achieve gender equality and empower all women and girls" (United Nations, 2015).

Indonesia menjadi negara kedua terbesar penyumbang sampah plastik di dunia (Jambeck et al., 2015). Jumlah timbulan sampah nasional sudah mencapai 65,2 juta ton pertahun. Angka ketidakpedulian terhadap pengelolaan sampah di Indonesia tergolong tinggi yaitu sebesar 35,53\%. Lebih dari separuh rumah tangga di Indonesia $(66,8 \%)$ menggunakan cara yang tidak ramah lingkungan ketika melakukan pengelolaan terhadap sampah, seperti membakar sampah yang akan menimbulkan polusi udara ataupun membuang sampah ke sungai, selokan dan sembarangan tempat (Safitri, Purba, \& Zulkifli, 2018).

Ibu rumah tangga merupakan kelompok masyarakat yang paling berpeluang besar untuk berperan aktif dalam program Bank Sampah karena didukung oleh ketersediaan sumber daya fisik maupun waktu yang mereka miliki (Gayatri, Hapsari, \& Aqil, 2018; Ikhwanul, Kawung, \& Waani, 2014). Negara berkembang dengan segala keterbatasannya baik dari sisi sumber daya manusia maupun kemampuan pembiayaan sebaiknya memilih sistem daur ulang sederhana melalui Bank Sampah karena dapat menjadi contoh implementasi model ekonomi sirkular yang cukup efektif (Wijayanti \& Suryani, 2015). Diakhir tahun 2017 Kementrian Lingkungan Hidup dan Kehutanan menyatakan bahwa telah ada 5.244 Bank Sampah di seluruh Indonesia yang tersebar di 34 provinsi dan menghasilkan pendapatan sebesar Rp 1,48 miliar. Sebanyak 163.128 orang diperkerjakan di seluruh Bank Sampah tersebut, dan 49 persen diantaranya adalah wanita yang sebagian besar merupakan ibu rumah tangga. Semua Bank Sampah tersebut juga sangat 
berperan secara signifikan dalam mengurangi sampah pada tahun 2017 yaitu sebesar 1,7\%. Oleh karena itu maka diketahui bahwa keberadaan Bank Sampah dapat memberikan dampak positif yaitu berupa kontribusi terhadap pengurangan sampah nasional sekaligus peluang pekerjaan untuk memberikan penghasilan tambahan.

Sebagai kota kecil di provinsi Sumatera Barat, Padang Panjang masih memiliki permasalahan dalam pengelolaan persampahannya. Data terakhir dari Dinas Perumahan Kawasan Permukiman dan Lingkungan Hidup Kota Padang Panjang menunjukkan bahwa peran Bank Sampah sebagai pusat pengolahan sampah dan edukasi masyarakat melalui cara daur ulang atau 3R (Reduce, Reuse and Recycle) belum optimal. Jumlah sampah yang terserap oleh Bank Sampah makin lama makin menurun hingga hanya sekitar 0,4 \% dari total timbulan sampah kota. Hal ini menunjukkan bahwa masyarakat belum termotivasi dan tersosialisasikan secara menyeluruh mengenai besarnya potensi ekonomi yang dimiliki jika seseorang menjadi nasabah Bank Sampah.

Data statistik Kota Padang Panjang menampilkan bahwa "mengurus rumah tangga" merupakan status non angkatan kerja yang signifikan yaitu 15,24 \% dari total jumlah penduduk atau sebesar 6400 jiwa dan sebanyak 5565 jiwa merupakan perempuan (Dewi et al., 2018). Angka ini menunjukkan potensi yang besar perempuan pengurus rumah tangga untuk dilibatkan partisipasi aktifnya dalam gerakan pengelolaan sampah domestik melalui Bank Sampah.

Literatur yang menjadi salah satu rujukan peneliti adalah oleh Gayatri dkk. Menurut Gayatri et al (2018) pendidikan pemanfaatan sumber daya, penumbuhan sikap peduli lingkungan, pelatihan keterampilan, penumbuhan jiwa kewirausahaan dan penumbuhan motivasi kemandirian merupakan indikator pemberdayaan perempuan yang dapat dilihat pada kegiatan Bank Sampah. Penelitian ini bersifat kualitatif tanpa menghitung nilai pemberdayaan yang diperoleh nasabah dari kegiatan Bank Sampah (Gayatri et al., 2018).

\section{TINJAUAN PUSTAKA}

Kerangka teoritis pada penelitian ini menyertakan beberapa konsep dan teori yang saling berhubungan, yaitu: Eksternalitas diartikan sebagai biaya ekonomi atau dampak dari hasil sampingan sebuah kegiatan ekonomi namun tidak dialokasikan dalam sistem pasar. Insentif untuk mempertimbangankan biaya eksternal atau manfaat yang dihasilkan tidak dilakukan tidak dimiliki oleh pembuat eksternalitas (Prasetyia, 2012). Eksternalitas merupakan biaya diluar aktivitas perusahaan dan tidak muncul dalam perhitungan laba rugi. Biaya eksternalitas tidak kalah nyata, terjadi dan dirasakan pada banyak masyarakat luas daripada perusahaan itu sendiri (Schiller, 2008). 
Sirkular Ekonomi didefenisikan sebagai suatu sistem ekonomi yang menggantikan konsep 'end-of-life' dengan mengurangi, secara alternatif menggunakan kembali, mendaur ulang dan memulihkan bahan yang diproses produksi / distribusi dan konsumsi. Ini berlaku ditingkat mikro (produk, perusahaan, konsumen), tingkat meso dan tingkat makro (kota, wilayah, negara dan sekitarnya), dengan tujuan untuk mencapai pembangunan berkelanjutan, dengan demikian secara bersamaan menciptakan kualitas lingkungan, kemakmuran ekonomi dan keadilan sosial, untuk manfaat generasi sekarang dan masa depan (Kirchherr, Reike, \& Hekkert, 2017). Ekonomi sirkular adalah istilah umum untuk ekonomi di mana pertumbuhan dipisahkan dari penggunaan sumber daya yang langka. Perusahaan dalam lingkaran ekonomi difokuskan pada penciptaan nilai berdasarkan pengelolaan sumber daya di pasar, sebagai lawan pengelolaan sumber daya yang semata-mata hanya dalam proses produksi. Hingga pada akhirnya, ekonomi sirkular menghasilkan rantai nilai nol limbah yang digerakkan oleh energi regeneratif (terbarukan), dan sumber daya alam lebih banyak bahkan hampir seluruhnya digunakan dalam hubungan lingkaran yang tertutup daripada hanya dikonsumsi kemudian dibuang dalam aliran yang linier (Lacy \& Rutqvist, 2015)

Bank Sampah merupakan satu cara pengelolaan sampah skala rumah tangga, yang berlandaskan pada pemberdayaan masyarakat. Sampah yang ditabung yaitu sampah yang sudah dipilah menurut jenisnya sehingga memudahkan pengelola melakukan proses pemilahan, kemudian diolah menjadi barang yang lebih bernilai ekonomi. Mekanisme kerja Bank Sampah menurut Peraturan Menteri Negara Lingkungan Hidup RI No. 13 tahun 2012 meliputi: Pemilahan sampah, penyerahan sampah ke Bank Sampah; penimbangan sampah, pencatatan, dan hasil penjualan sampah yang diserahkan dimasukkan ke dalam buku tabungan; dan bagi hasil penjualan sampah antara penabung dan pelaksana (Indonesia, 2012).

Secara teoritis, pemberdayaan didefenisikan sebagai sebuah kegiatan atau upaya seseorang atau kelompok dalam proses pembangunan. Kegiatan tersebut harus melibatkan partisipasi dan peran aktif individu atau kelompok masyarakat tersebut dengan tujuan untuk memperbaiki keadaan mereka sendiri. Pemberdayaan menuntut masyarakat tersebut untuk menjadi subjek aktif bukan lagi menjadi objek yang bersifat pasif (Lincoln, Travers, Ackers, \& Wilkinson, 2002). Pemberdayaan perempuan sebanding dengan penekanan pada literatur tentang pemberdayaan secara keseluruhan, yaitu tentang menghasilkan kebutuhan akan informasi dan akuntabilitas serta bagaimana memfasilitasi inklusifitas, partisipasi, dan mobilisasi dari mereka yang berada dalam posisi yang kurang beruntung atau perempuan (The World Bank, 2005). 


\section{METODE PENELITIAN}

Penelitian survey ini dilaksanakan di Bank Sampah Kurabu Kota Padang Panjang Provinsi Sumatera Barat. Jumlah sampel sebanyak 74 responden dari 127 nasabah. Daftar pertanyaan dibuat menggunakan teknik pengskalaan likert berbentuk ordinal, yaitu mengurutkan data objek dari peringkat terendah hingga tertinggi atas persepsi responden tanpa diketahui selisih antara satu tanggapan dengan tanggapan lainnya (Harpe, 2015). Penentuan lokasi dan sampel dilakukan dengan metode purposive sampling atau secara sengaja sesuai kriteria yang dibutuhkan dalam riset, yaitu nasabah Bank Sampah Kurabu yang berstatus sebagai Ibu Rumah Tangga (IRT). Penelitian menggunakan pendekatan deskriptif kuantitatif yang menganalisis variabel penelitian dengan prosedur statistik. Tujuan penelitian yaitu menganalisis pengaruh keikutsertaan nasabah berstatus Ibu Rumah Tangga di kegiatan Bank Sampah terhadap pemberdayaannya.

Analisis dilakukan dengan metode pemodelan struktural atau Stuctural Equation Modelling-Partial Least Square (SEM-PLS) menggunakan aplikasi SmartPLS V.3.2.9. Terdapat tiga kelompok hubungan dari model analisis jalur semua variabel laten dalam PLS yaitu model outer, model inner, dan weight relation. Model jalur tersebut selanjutnya dikonversi ke dalam bentuk persamaan struktural PLS untuk menyatakan kausalitas antar berbagai konstruk sebagai berikut:

- Model Outer

Untuk variabel laten eksogen (reflektif):

$$
\begin{aligned}
& \mathrm{x} 1=\lambda \times 1 \xi 1+\delta 1 \\
& \mathrm{x} 2=\lambda \times 2 \xi 2+\delta 2 \\
& \mathrm{x} 3=\lambda \times 3 \xi 3+\delta 3 \\
& \mathrm{x} 4=\lambda \times 4 \xi 4+\delta 4 \\
& \mathrm{x} 5=\lambda \times 5 \xi 5+\delta 5
\end{aligned}
$$

Untuk variabel laten endogen (reflektif) $\mathrm{y} 1=\lambda \mathrm{y} 1 \eta 1+\varepsilon 1$

- Model inner :

$\eta 1=\gamma 1 \xi 1+\gamma 2 \xi 2+\gamma 3 \xi 3+\gamma 4 \xi 4+\zeta 1$

Keterangan:

$\xi=$ variabel laten eksogen

$\eta=$ variabel laten endogen

$\lambda \mathrm{x}=$ loading factor variabel laten eksogen

$\lambda \mathrm{y}=$ loading factor variabel laten endogen 
$\gamma=$ koefisien pengaruh eksogen pada endogen

$\delta=$ galat pengukuran pada variabel laten eksogen

$\varepsilon=$ galat pengukuran pada variabel laten.

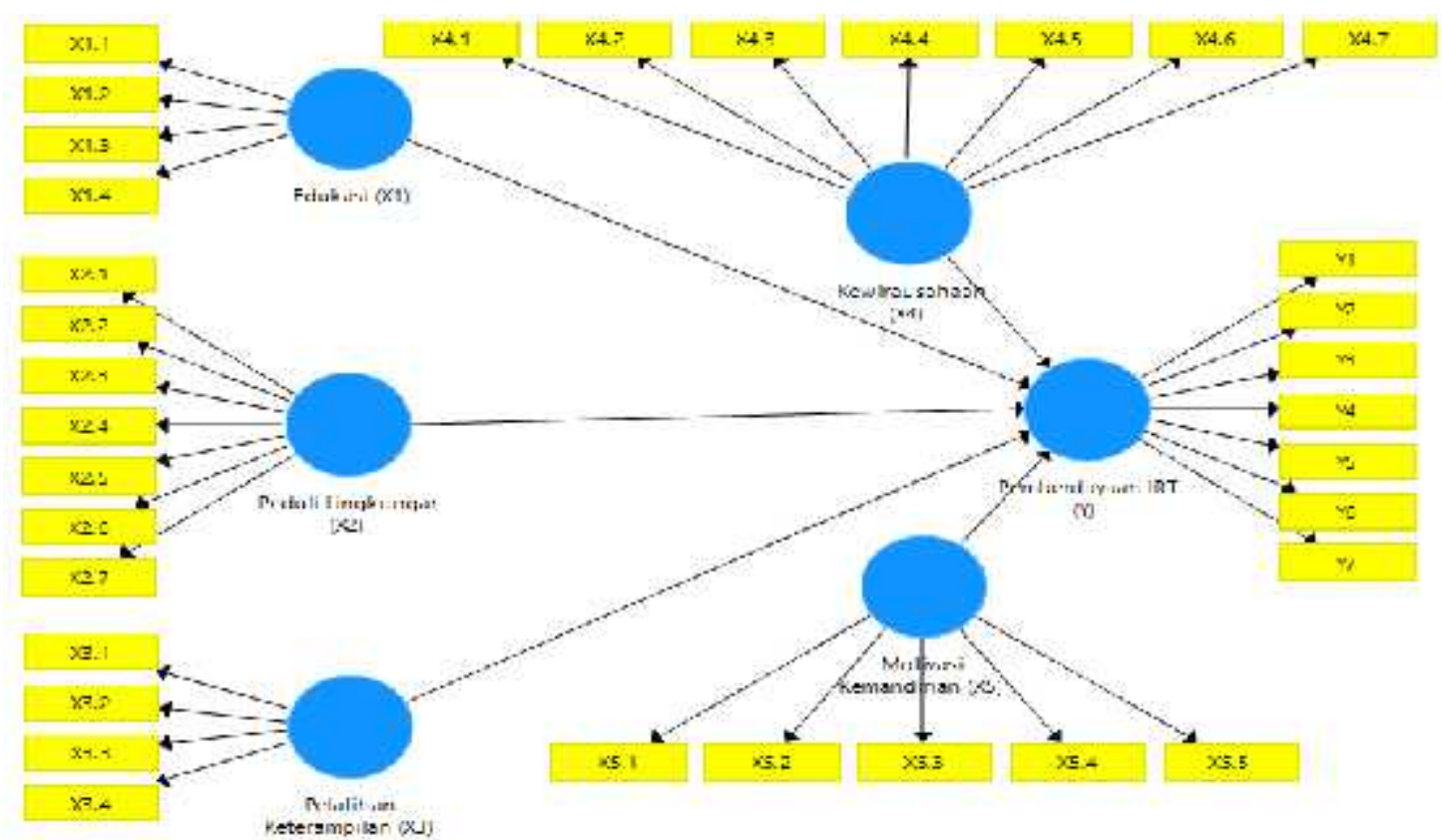

Gambar 1. Model Struktural Penelitian

Konstruksi model menggambarkan hubungan lima variabel eksogenous (kegiatan Bank Sampah) terhadap satu variabel endogenous (pemberdayaan). Terdapat enam konstruk laten dengan 34 indikator pengukuran. Variabel penelitian ini mengakomodasi dimensi perhitungan pemberdayaan perempuan yang merupakan adaptasi dari kombinasi tiga sumber literatur. Chung dkk menyatakan bahwa komponen penentu pemberdayaan perempuan adalah kontribusi ekonomi, pendidikan, pemerintahan, kesehatan dan media (Chung, Kantachote, Mallick, Polster, \& Kelsey Roets, 2013). Sedangkan (Malhotra, 2003) secara spesifik mengklasifikasikan indikator pemberdayaan perempuan pada tiga sektor berbeda yaitu sektor rumah tangga atau domestik, sektor komunitas dan sektor global. Adapun indikator rumah tangga yaitu ekonomi, sosial budaya, hubungan antar anggota keluarga, hukum, politik dan psikologi. Penelitian ke-3 yang menjadi sumber rujukan penulis dalam penentuan variabel penelitian adalah Gayatri dkk yang menyatakan bahwa pendidikan pemanfaatan sumber daya, penumbuhan sikap peduli lingkungan, pelatihan keterampilan, penumbuhan jiwa kewirausahaan dan penumbuhan motivasi kemandirian merupakan indikator pemberdayaan perempuan yang dapat dilihat pada kegiatan Bank Sampah (Gayatri et al., 2018).

Model terdiri dari Variabel Laten endogenous dan Variabel Laten Eksogenous denga hubungan formatif dimana variabel Laten Endogenous merupakan Pemberdayaan Ibu Rumah Tangga yang terdiri dari beberapa faktor yaitu: a) Sosial Budaya; b) Kontribusi Ekonomi; c) 
Pendidikan; d) Media; e) Kesehatan; f) Pemerintahan dan g) Keluarga atau interpersonal. Variabel Laten Eksogenous merupakan: a) Pendidikan pemanfaatan sumber daya di Bank Sampah; b) Penumbuhan sikap peduli lingkungan di Bank Sampah; c) Pelatihan Keterampilan di Bank Sampah; d) Penumbuhan Jiwa Kewirausahaan di Bank Sampah dan e) Penumbuhan motivasi kemandirian di Bank Sampah (Gayatri et al., 2018).

\section{HASIL \& PEMBAHASAN}

\section{A. Analisis Deskriptif}

Analisis deskriptif diartikan oleh Sugiyono (2012) sebagai sebuah analisis statistik dan menggambarkan obyek yang diteliti melalui data sampel sebagaimana adanya tanpa melakukan analisis dan membuat kesimpulan yang berlaku umum dalam penelitian (Sugiyono, 2012).

Berdasarkan Tabel 1 diketahui bahwa usia responden di dominasi oleh Ibu Rumah Tangga paruh baya (40 s/d 51 tahun) sebanyak 45\%. Jumlah anggota keluarga responden didominasi kategori 0 s/d 10 orang yang menjadi "produsen" timbulan sampah rumah tangga. Dari lama keanggotaan terlihat ketika awal didirikan animo untuk menjadi nasabah di Bank Sampah Kurabu cukup tinggi dan kecenderungan tersebut semakin menurun pada kurun waktu satu tahun terakhir. Rata-rata tabungan sampah anorganik responden tergolong kecil karena sebanyak $64 \%$ di dominasi oleh rata-rata tabungan dibawah $5 \mathrm{Kg} / \mathrm{bulan}$.

Sebagian besar responden telah pernah mengikuti berbagai kegiatan di Bank Sampah terutama sosialisasi program dan pengelolaan sampah organik. Namun kegiatan pelatihan pembuatan produk 3R dan Bimtek produksi dan pemasaran produk 3R masih sedikit diikuti yaitu hanya $22 \%$ dan $42 \%$. Rata-rata pendapatan sebulan dari menjadi nasabah Bank Sampah dari didominasi oleh penghasilan terendah (Rp.0,- s/d Rp.95.000,-) sebanyak $61 \%$. Hanya dua orang responden yang memiliki rata-rata penghasilan perbulan besar atau sama dengan Rp.300.000,- dari kegiatan menabung sampah anorganik di Bank Sampah.

Tabel 1. Demografi dan Karakteristik Responden

\begin{tabular}{|c|c|c|c|}
\hline No. & Karakteristik & Frekuensi & (\%) \\
\hline \multirow[t]{8}{*}{1} & Umur & 74 & 100 \\
\hline & a. $22-27$ & 7 & 9 \\
\hline & b. $28-33$ & 5 & 7 \\
\hline & c. $34-39$ & 11 & 15 \\
\hline & d. $40-45$ & 16 & 22 \\
\hline & e. $46-51$ & 17 & 23 \\
\hline & f. $52-57$ & 9 & 12 \\
\hline & g. $58-63$ & 7 & 9 \\
\hline
\end{tabular}

\begin{tabular}{|c|c|c|c|}
\hline No. & Karakteristik & Frekuensi & (\%) \\
\hline \multirow[t]{5}{*}{6} & $\begin{array}{l}\text { Jumlah Anggota Keluarga dalam } \\
\text { Rumah }\end{array}$ & 74 & 100 \\
\hline & a. $0 \mathrm{~s} / \mathrm{d} 5$ orang & 32 & 43 \\
\hline & b. $6 \mathrm{~s} / \mathrm{d} 10$ orang & 30 & 41 \\
\hline & a. $11 \mathrm{~s} / \mathrm{d} 15$ orang & 9 & 12 \\
\hline & b. $16 \mathrm{~s} / \mathrm{d} 20$ orang & 3 & 4 \\
\hline \multirow[t]{3}{*}{7} & $\begin{array}{l}\text { Lama Keanggotaan di Bank } \\
\text { Sampah }\end{array}$ & 74 & 100 \\
\hline & a. $\quad<1$ tahun & 7 & 9 \\
\hline & b. $1 \mathrm{~s} / \mathrm{d} 2$ tahun & 12 & 16 \\
\hline
\end{tabular}




\begin{tabular}{|c|c|c|c|c|c|c|c|}
\hline & h. $64-69$ & 2 & 3 & & $2 \mathrm{~s} / \mathrm{d} 3$ tahun & 10 & 14 \\
\hline \multirow[t]{6}{*}{2} & Pendidikan & 74 & 100 & & 3 s/d 4 tahun & 6 & 8 \\
\hline & a. Tidak tamat SD & 4 & 5 & & $4 \mathrm{~s} / \mathrm{d} 5$ tahun & 18 & 24 \\
\hline & b. Sekolah Dasar & 9 & 12 & & f. $>5$ tahun & 21 & 28 \\
\hline & $\begin{array}{l}\text { c. Sekolah Menengah } \\
\text { Pertama }\end{array}$ & 17 & 23 & 8 & $\begin{array}{l}\text { Rata-Rata tabungan sampah } \\
\text { anorganik/ bulan }\end{array}$ & 74 & 100 \\
\hline & $\begin{array}{l}\text { d. Sekolah Menengah } \\
\text { Atas }\end{array}$ & 37 & 50 & & a. $\quad<5 \mathrm{Kg}$ & 47 & 64 \\
\hline & e. Perguruan Tinggi & 7 & 9 & & $5 \mathrm{~s} / \mathrm{d} 10 \mathrm{Kg}$ & 16 & 22 \\
\hline \multirow[t]{3}{*}{3} & Status Perkawinan & 74 & 100 & & $10 \mathrm{~s} / \mathrm{d} 15 \mathrm{Kg}$ & 9 & 12 \\
\hline & a. Kawin & 55 & 74 & & d. $>15 \mathrm{Kg}$ & 2 & 3 \\
\hline & b. Janda & 19 & 26 & 9 & $\begin{array}{l}\text { Kegiatan yang pernah diikuti di } \\
\text { Bank Sampah }\end{array}$ & 74 & 100 \\
\hline \multirow[t]{2}{*}{4} & Status Rumah & 74 & 100 & & a. Menabung Sampah & 74 & 100 \\
\hline & a. Hak Milik & 53 & 72 & & $\begin{array}{l}\text { b. Sosialisasi Program Bank } \\
\text { Sampah }\end{array}$ & 74 & 100 \\
\hline \multirow[t]{2}{*}{ No. } & Karakteristik & Frekuensi & (\%) & No. & Karakteristik & Frekuensi & $(\%)$ \\
\hline & b. Kontrak & 21 & 28 & & $\begin{array}{l}\text { c. Pelatihan Pengolahan } \\
\text { Sampah Organik }\end{array}$ & 61 & 82 \\
\hline \multirow[t]{5}{*}{5} & $\begin{array}{l}\text { Sumber Penghasilan } \\
\text { dari }\end{array}$ & 74 & 100 & & $\begin{array}{l}\text { d. Pelatihan Pembuatan } \\
\text { Peroduk } \\
\quad 3 \mathrm{R}\end{array}$ & 31 & 42 \\
\hline & a. Suami & 55 & 74 & & $\begin{array}{l}\text { e. Bimtek Produksi dan } \\
\text { Pemasaran Produk 3R }\end{array}$ & 16 & 22 \\
\hline & b. Anak & 35 & 47 & & f. Tidak ada & 0 & 0 \\
\hline & $\begin{array}{l}\text { c. Anggota Keluarga } \\
\text { yang Lain } \\
\text { d. Program Bantuan } \\
\text { Sosial }\end{array}$ & 41 & 55 & 10 & $\begin{array}{l}\text { Rata-Rata Peningkatan } \\
\text { Pendapatan per bulan } \\
\text { setelah menjadi Nasabah Bank } \\
\text { Sampah }\end{array}$ & 74 & 100 \\
\hline & e. Mandiri & 11 & 15 & & a. Rp.0,- s/d Rp.95.000,- & 45 & 61 \\
\hline \multirow[t]{5}{*}{6} & $\begin{array}{l}\text { Jumlah Anggota } \\
\text { Keluarga dalam Rumah }\end{array}$ & 74 & 100 & & $\begin{array}{l}\text { b. Rp.100.000,- s/d } \\
\text { Rp.195.000,- }\end{array}$ & 21 & 28 \\
\hline & a. $\quad 0 \mathrm{~s} / \mathrm{d} 5$ orang & 32 & 43 & & $\begin{array}{l}\text { c. Rp. } 200.000,-s / d \\
\text { Rp. } 295.000,-\end{array}$ & 6 & 8 \\
\hline & b. $\quad 6 \mathrm{~s} / \mathrm{d} 10$ orang & 30 & 41 & & $\begin{array}{l}\text { d. } \quad \text { Rp.300.000,- s/d } \\
\text { Rp.395,000,- }\end{array}$ & 2 & 3 \\
\hline & c. $\quad 11 \mathrm{~s} / \mathrm{d} 15$ orang & 9 & 12 & & Sumber: Pengolahan Data Kuisi & & \\
\hline & d. 16 s/d 20 orang & 3 & 4 & & & & \\
\hline
\end{tabular}

\section{B. Analisis Inferensial dan Temuan Empiris}

Analisis inferensial adalah kumpulan cara atau metode pengolahan data untuk menarik kesimpulan ataupun menguji hipotesis. Analisis inferensial terbagi menjadi teknik statistik inferensial parametrik dan teknik statistik inferensial non parametrik. Teknik statistik inferensial parametrik memfasilitasi seorang peneliti menggunakan alat analisis yang sesuai dengan model penelitian. SEM atau Structural Equation Modelling umumnya digunakan dalam analisis kausalitas. Path Analysis dapat digunakan untuk menganalisis kausalitas jalur (Sholihin \& Ratmono, 2013; Sugiyono, 2012)

\section{B.1. Evaluasi Model Pengukuran (Outer Model)}




\section{1) Reliabilitas Indikator}

Pengujian reliabilitas indikator digunakan untuk menilai apakah suatu indikator pengukuran variabel laten reliabel atau tidak. Jika hasil pengukuran tidak memenuhi nilai batas minimum, maka indikator tersebut dapat tidak diikutkan dalam pengukuran. Hasil outer loading tiap indikator menunjukkan terdapat enam konstruk yang nilai loadingnya dibawah 0,7 yang berarti keenam konstruk tersebut tidak cukup menjelaskan sebanyak $50 \%$ dari varians indikatornya sehingga harus dihapus dari model struktural tersebut. Keenam konstruk itu adalah X2,6; X4.6; X4.7; Y2 dan Y5. Hasil evaluasi reliabilitas tersebut akhirnya menyisakan total 28 konstruk indikator yang sudah reliable seperti pada gambar 2 .

\section{2) Internal Consistensi Reliability dan Validitas Konvergen}

Internal Consistency Reliability berfungsi untuk mengetahui seberapa besar konstruk laten dapat diukur oleh indikatornya. Pengukuran ini menggunakan instrumen yang disebut dengan composite reliability dan Cronbach's alpha. Nilai composite reliability 0,6 - 0,7 dianggap memiliki reliabilitas yang baik, dan nilai Cronbach'salpha yang diharapkan adalah di atas 0,7 (Garson, 2016). Dari hasil analisis data penelitian diketahui bahwa keenam variabel laten memenuhi batasan nilai yang dipersyaratkan sehingga semua indikator mampu mengukur konstruk latennya.

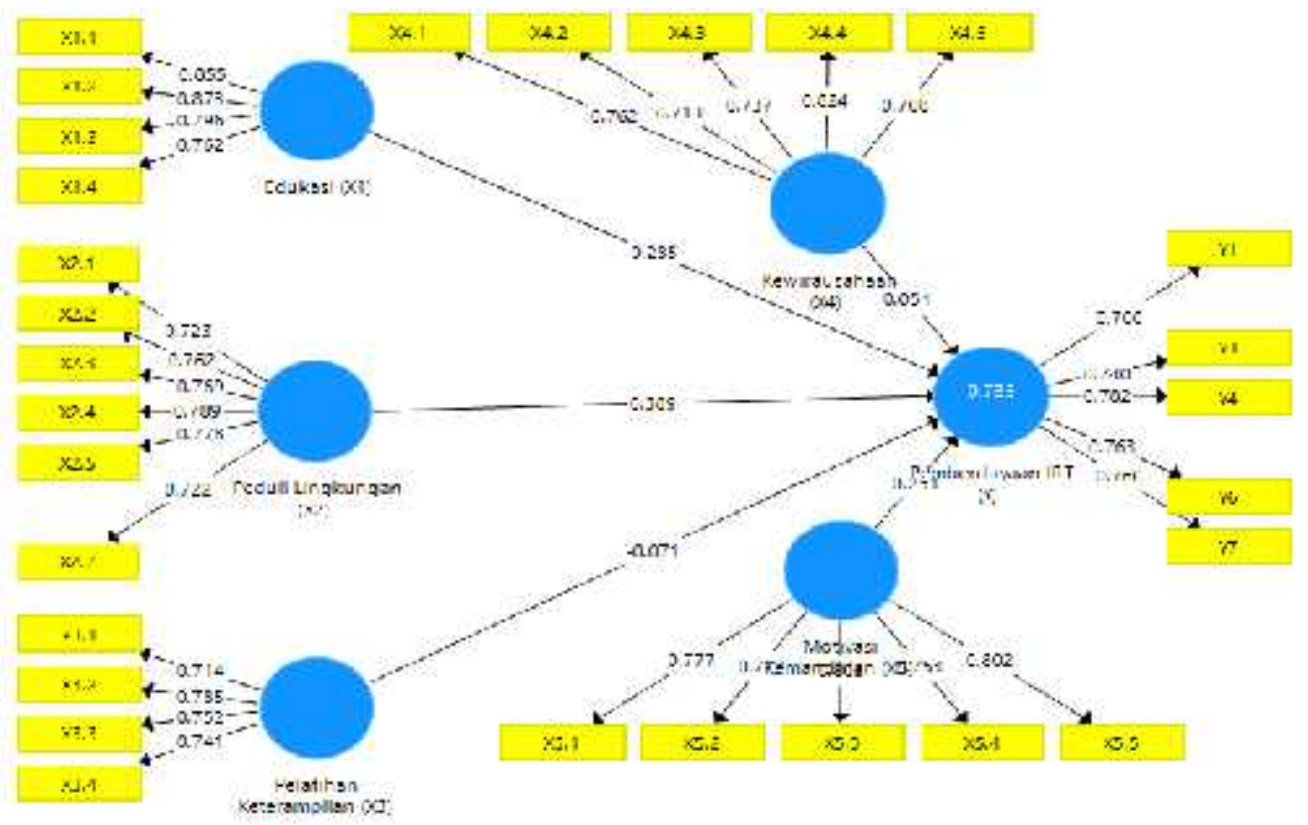

Gambar 2. Model Hasil Uji Outer Loading

Tabel 2. Hasil Uji Internal Konsistensi Reliability dan Validitas Konvergen 


\begin{tabular}{|c|c|c|c|c|c|}
\hline \multicolumn{4}{|c|}{ Anno Suliza ${ }^{1}$, Fery Andrianus 2, Chairul 3/ Ekonika 05 (2) 2020} & ISSN (Print) & 2502-9304 \\
\hline No & Variabel & $\begin{array}{c}\text { Cronbach's } \\
\text { Alpha }\end{array}$ & \multirow{2}{*}{$\begin{array}{c}\text { rho- } \\
\text { A } \\
0,84\end{array}$} & $\begin{array}{l}\text { Composite } \\
\text { Reliability }\end{array}$ & $\begin{array}{l}\text { Average } \\
\text { Variance } \\
\text { Extracte } \\
d(A V E)\end{array}$ \\
\hline & & & & & \\
\hline \multirow[t]{2}{*}{1} & Edukasi pemanfaatan sumber daya (X1) & 0,840 & 9 & 0,893 & 0,677 \\
\hline & Penumbuhan sikap peduli lingkungan & & 0,85 & & \\
\hline \multirow[t]{2}{*}{2} & $(\mathrm{X} 2)$ & 0,852 & 6 & 0,890 & 0,574 \\
\hline & & & 0,75 & & \\
\hline \multirow[t]{2}{*}{3} & Pelatihan Keterampilan (X3) & 0,742 & 0 & 0,836 & 0,560 \\
\hline & & & 0,81 & & \\
\hline \multirow[t]{2}{*}{4} & Penumbuhan Jiwa Kewirausahaan (X4) & 0,805 & 3 & 0,865 & 0,562 \\
\hline & & & 0,83 & & \\
\hline \multirow[t]{2}{*}{5} & Motivasi Kemandirian (X5) & 0,828 & 1 & 0,879 & 0,594 \\
\hline & & & 0,82 & & \\
\hline 6 & Pemberdayaan IRT (Y) & 0,820 & 3 & 0,874 & 0,581 \\
\hline
\end{tabular}

Sumber: hasil analisis data penelitian

Average Variance Extracted (AVE) digunakan untuk mengukur Validitas konvergen sebuah konstruk terhadap indikator reflektifnya. Nilai AVE yang diterima adalah sama dengan 0,5 atau lebih. Nilai AVE 0,5 atau lebih berarti konstruk dapat menjelaskan 50\% atau lebih varians itemnya. (Sholihin \& Ratmono, 2013). Nilai AVE pada hasil penelitian menunjukkan semuanya bernilai > 0,5. Hal ini menunjukkan bahwa konstruk mampu menjelaskan sebagian atau lebih dari varians itemnya.

\section{B.2. Evaluasi Model Struktural (Inner Model)}

Langkah awal evaluasi model struktural adalah mengecek adanya kolinearitas antar konstruk dan kemampuan prediktif model. Kemudian dilanjutkan dengan mengukur kemampuan prediksi model menggunakan koefisien determinasi $\left(\mathrm{R}^{2}\right)$ (Ghozali, Imam, 2015).

\section{1) Variance Inflation Factor (VIF)}

Evaluasi kolinearitas dilakukan dengan menggunakan Variance Inflation Factor (VIF) pada aplikasi SmartPLS v.3.2.9. Multikolinearitas menyebabkan kemampuan prediksi model tidak baik karena adanya fenomena di mana dua atau lebih variabel bebas atau konstruk eksogen berkorelasi tinggi. Nilai VIF harus kurang dari 5, karena bila lebih dari 5 mengindikasikan adanya kolinearitas antar konstruk (Sholihin \& Ratmono, 2013). Hasil penelitian menunjukkan nilai VIF yang semuanya $<5$ sehingga tidak terdapat kolinearitas antar variabel bebas pada model yang digunakan.

\section{2) Koefisien Determinasi $\left(\mathbf{R}^{2}\right)$}

Cara untuk menilai seberapa besar konstruk endogen/variabel terikat dapat dijelaskan oleh konstruk eksogen/variabel bebasnya adalah menggunakan koefisien determinasi $\left(\mathrm{R}^{2}\right)$. 
Nilai koefisien determinasi $\left(\mathrm{R}^{2}\right)$ diharapkan antara 0 dan 1 . Nilai $\mathrm{R}^{2} 0,75,0,50$, dan 0,2 menunjukkan bahwa model kuat, moderat, dan lemah (Sholihin \& Ratmono, 2013). Berdasarkan hasil penelitian diperoleh bahwa nilai R Square sebesar 0,735 dengan kategori "kuat" sehingga variabel bebas mampu menjelaskan 73,5\% variabel terikatnya dan sisanya $(26,5 \%)$ dijelaskan oleh variabel tau faktor lain di luar penelitian.

\section{B.5. Uji Hipotesis (Resampling Bootsraping)}

Pengujian hipotesis menggunakan prosedur bootstrapping dimana akan dihasilkan nilai t-statistik untuk setiap jalur hubungan yang digunakan. Nilai t-statistik tersebut selanjutnya dibandingkan dengan nilai t-tabel. Penelitian menggunakan tingkat kepercayaan 95\% sehingga tingkat presisi atau batas ketidakakuratan $(\alpha)=5 \%=0,05$, nilai t-tabelnya adalah 1,96 . Jika nilai t-statistik lebih kecil dari nilai t-tabel ( $\mathrm{t}$-statistik $<1.96$ ), maka Ho diterima dan Ha ditolak. Jika nilai t-statistik lebih besar atau sama dengan t-tabel ( $\mathrm{t}$-statistik > 1.96 ), maka Ho ditolak dan Ha diterima (Ghozali, Imam, 2015).

Tabel 3. Hasil Uji Hipotesis (Resampling Bootsraping)

\begin{tabular}{|c|c|c|c|c|c|}
\hline No & Diagram Path & $\begin{array}{c}\text { Standar } \\
\text { deviation } \\
\text { (STDEV) }\end{array}$ & $\begin{array}{l}\text { T Statistics } \\
\text { (IO/STDEVI) }\end{array}$ & P Values & Kesimpulan \\
\hline 1 & $\begin{array}{l}\text { Edukasi pemanfaatan sumber daya (X1) ---> } \\
\text { Pemberdayaan IRT (Y) }\end{array}$ & 0,120 & 2,383 & 0,018 & Signifikan \\
\hline 2 & $\begin{array}{l}\text { Penumbuhan sikap peduli lingkungan (X2) ---> } \\
\text { Pemberdayaan IRT (Y) }\end{array}$ & 0,161 & 2,383 & 0,018 & Signifikan \\
\hline 3 & $\begin{array}{l}\text { Pelatihan Keterampilan (X3) ---> Pemberdayaan IRT } \\
\text { (Y) }\end{array}$ & 0,108 & 0,659 & 0,510 & $\begin{array}{l}\text { Tidak } \\
\text { signifikan }\end{array}$ \\
\hline 4 & $\begin{array}{l}\text { Penumbuhan Jiwa Kewirausahaan (X4) ---> } \\
\text { Pemberdayaan IRT (Y) }\end{array}$ & 0,149 & 0,363 & 0,717 & $\begin{array}{l}\text { Tidak } \\
\text { signifikan }\end{array}$ \\
\hline 5 & Motivasi Kemandirian (X5) ---> Pemberdayaan IRT (Y) & 0,148 & 1,699 & 0,090 & $\begin{array}{c}\text { Tidak } \\
\text { signifikan }\end{array}$ \\
\hline
\end{tabular}

Sumber: Hasil Analisis Data Penelitiaan

Hasil penelitian menunjukkan nilai t-statistik yang lebih besar atau sama dengan nilai t-tabel terdapat pada variabel Edukasi Pemanfaatan Sumber Daya ( X1) dan Penumbuhan Sikap Peduli Lingkungan (X2). Sedangkan tiga variabel lainnya; Pelatihan Keterampilan (X3), Penumbuhan Jiwa Kewirausahaan (X4) dan Motivasi Kemandirian (X5) masih berada di bawah nilai t- tabel sehingga tiga hipotesis untuk variabel tersebut ditolak.

\section{SIMPULAN \& SARAN}

\section{Kesimpulan}

Konsistensi hasil deskripsi data demografi dan karakteristik responden mampu dibuktikan oleh hasil analisa data pada analisis inferensial dan temuan empiris. Jika pada data deskriptif terdapat informasi mengenai dua kegiatan Bank Sampah yang sedikit diikuti responden (Pelatihan keterampilan dan Bimtek Pemasaran Produk 3R), maka hasil uji hipotesis 

variabel yang identik dengan deskripsi tersebut juga ditolak atau tidak signifikan mempengaruhi pemberdayaan IRT (variabel endogenous) yaitu "pelatihan keterampilan" dan "penumbuhan jiwa kewirausahaan". Sedangkan untuk variabel "motivasi kemandirian" hasil analisanya masih kurang signifikan mempengaruhi pemberdayaan.

Model analisa data penelitian dan data hasil survey kuisioner dari responden secara umum tergolong baik. Karena secara konsisten memenuhi setiap kriteria uji dan perhitungan yang telah dilakukan menggunakan aplikasi SmartPLS v.3.2.9.2019 yaitu: uji reliabilitas, validitas, kolinearitas dan koefisien determinasi.

Pemberdayaan Ibu Rumah Tangga yang menjadi objek pengukuran pada penelitian ini mampu ditunjukkan perwujudannya melalui program Bank Sampah karena dari lima variabel yang diujikan terdapat dua variabel yang secara signifikan mempengaruhinya. Tiga variabel lain yang tidak signifikan tersebut berkorelasi positif dengan hasil survey dan indepth interview yang telah peneliti lakukan. Kegiatan Bank Sampah yang walaupun terlihat aktif namum sebenarnya tidak terlalu menyerap partisipasi aktif anggotanya secara keseluruhan. Hanya sebagian kecil dari anggota/ nasabah Bank Sampah saja yang "rajin" menabung sampah, membuat produk 3R dan mengikuti program pelatihan atau bimbingan teknis lainnya.

\section{Saran}

Segala fasilitas infrastruktur (fisik dan aspek legal), program bimbingan dan pendampingan dari Pemerintah Daerah untuk Bank Sampah telah cukup dipenuhi. Konsistensi seluruh stake holder yang terlibat dibutuhkan untuk menjaga keberlangsungan realisasi program Bank Sampah, khususnya anggota dan nasabah. Penegasan kebijakan "satu KK (Kepala Keluarga), satu akun Bank Sampah" hendaknya telah mulai dapat digulirkan oleh pemerintah daerah agar semangat pendaur ulangan sampah lebih bersifat menyeluruh di masyarakat dan rencana program pembangunan berkelanjutan dapat diwujudkan.

\section{DAFTAR PUSTAKA}

Chung, B., Kantachote, K., Mallick, A., Polster, R., \& Kelsey Roets. (2013). Indicators of Women' s Empowerment in Developing Nations By. Robert M.La Follette School Of Public Affairs, 1-95.

Dewi, H. K., Ananda, F., Lubis, L. F., El Haq, M. F., Rizal, S., Juliani, G., \& Primadini, R. (2018). Kota Padang Panjang Dalam Angka Padang Panjang Municipality In Figures 2018. Padang Panjang: Badan Pusat Statistik/BPS-Statistics Indonesia.

Garson, G. D. (2016). Partial Least Squares: Regression \& Structural Equation Models. In G. David Garson and Statistical Associates Publishing. 
Gayatri, A. M., Hapsari, S., \& Aqil, D. I. (2018). Housewife Empowerment Training Skills through Processing Waste Products to be Economic Value. Journal of Nonformal Education and Community Empowerment, 1(2), 120-127. https://doi.org/10.15294/pls.v1i2.17125

Ghozali, Imam, H. L. (2015). Konsep, Teknik, Aplikasi Menggunakan Smart PLS 3.0 Untuk Penelitian Empiris. Semarang: BP Undip.

Harpe, S. E. (2015). How to analyze Likert and other rating scale data. Currents in Pharmacy Teaching and Learning, 7(6), 836-850. https://doi.org/10.1016/j.cptl.2015.08.001

Ikhwanul, P. R., Kawung, E. J. R., \& Waani, N. (2014). Peran Ibu Rumah Tangga Nelayan Dalam Upaya Meningkatkan Perekonomian Keluarga di Kelurahan Bitung Karang Ria Kecamatan Tuminting Kota Manado. "Acta Diurna," III(4).

Indonesia, K. L. H. dan K. (2012). Peraturan Menteri Negara Lingkungan Hidup Republik Indonesia Nomor 13 Tahun 2012 Tentang Pedoman Pelaksanaan Reduce, Reuse, Dan Recycle Melalui Bank Sampah. Retrieved from http://widyacipta.com/file-pdf/IND-PUU7-2012-Permen LH 13 th 2012 bank sampah.pdf

Ir. Anton Manurung, M. ., Eni Lestariningsih, S.Si, M. ., Amiek Chamami, SST, M. S., Gaib Hakiki, S., Hasti Amanda I.P., S., Sugeng Supriyanto, SST, M. S., ... Maarif Ibnu Khoer, S.ST, M. S. (2015). Perempuan indonesia 2011-2015. Kementerian Pemberdayaan Perempuan dan Perlindangan Anak (KPP dan PA).

Jambeck, J. R., Perryman, M., 1, Geyer, * Roland, Andrady, A., Wilcox, C., ... 7. (2015). Plastic waste inputs from land into the ocean. Science, 347(Marine Pollution), 768. https://doi.org/10.1126/science.1260352

Kirchherr, J., Reike, D., \& Hekkert, M. (2017). Resources, Conservation \& Recycling Conceptualizing the circular economy : An analysis of 114 de fi nitions. 127(September), 221-232. https://doi.org/10.1016/j.resconrec.2017.09.005

Lacy, P., \& Rutqvist, J. (2015). Waste to Wealth : The Circular Economy Advantage (1st ed.). https://doi.org/10.1057/9781137530707

Lincoln, N. D., Travers, C., Ackers, P., \& Wilkinson, A. (2002). The meaning of empowerment: The interdisciplinary etymology of a new management concept. International Journal of Management Reviews, 4(3), 271-290. https://doi.org/10.1111/1468-2370.00087

Malhotra, A. (2003). Conceptualizing And Measuring Women's Empowerment As A Variable In International Development. washington DC.

Prasetyia, ferry. (2012). Teori Eksternalitas. Malang: UB-Press.

Safitri, P. A., Purba, W. S., \& Zulkifli, M. (2018). Statistik Lingkungan Hidup Indonesia 2018. Retrieved from https://www.bps.go.id 
Schiller, B. R. (2008). The Economy Today (11th ed.; D. Reiner, ed.). New York: McGraw-Hill.

Sholihin, M., \& Ratmono, D. (2013). Analisis SEM-PLS dengan Warp PLS 3.0 untuk Hubungan Nonlinier dalam Penelitian Sosial dan Bisnis (Ed. 1, Cet). yogyakarta: Andi Offset,.

Sugiyono, P. D. (2012). Metode Penelitian Kuantitatif Kualitatif dan R\&D. Bandung: alpha beta.

The World Bank. (2005). Book Review: Measuring empowerment: cross-disciplinary perspectives. In D. Narayan (Ed.), Progress in Development Studies (Vol. 6). washington DC: The International Bank for Reconstruction and Development.

United Nations. (2015). Transforming our World : The 2030 Agenda For Sustainable Development. Undp. Retrieved from https://www.globalamalen.se/

Wijayanti, D. R., \& Suryani, S. (2015). Waste Bank as Community-based Environmental Governance: A Lesson Learned from Surabaya. Procedia - Social and Behavioral Sciences, 184(August 2014), 171-179. https://doi.org/10.1016/j.sbspro.2015.05.077

World-Bank. (2018). The Global Gender Gap Report 2018 Insight Report. Retrieved from www.weforum.org 